\title{
KEEFEKTIFAN MODEL MAKE A MATCH BERBANTU MEDIA TABEL PERKALIAN TERHADAP MOTIVASI BELAJAR MATEMATIKA
}

\author{
Risha Ardhanty ${ }^{1}$, Mila Karmila ${ }^{2}$, Suyitno ${ }^{3}$ \\ 1,2,3 Jurusan Pendidikan Guru Sekolah Dasar, Fakultas IImu Pendidikan,Universitas PGRI Semarang \\ email : risha14.ra@gmail.com¹, milakarmila123@gmail.com² \\ suyitno34@gmail.com
}

\begin{abstract}
Abstrak
Motivasi adalah sesuatu yang mendorong seseorang belajar atau melakukan suatu kegiatan. Mc. Donald dalam Djamarah (2011: 148) mengatakan bahwa motivasi adalah suatu perubahan energi di dalam pribadi seseorang yang ditandai dengan timbulnya afektif (perasaan) dan reaksi untuk mencapai tujuan. Rendahnya motivasi belajar mengakibatkan siswa kurang antusias dan tidak percaya diri maka keinginan atau kemauan untuk melakukan sesuatu juga menjadi berkurang. Dengan menggunakan model pembelajaran Make $A$ Match berbantu media tabel perkalian diharapkan lebih efektif terhadap motivasi belajar siswa. Penelitian ini bertujuan untuk mengetahui efektif tidaknya model Make $A$ Match berbantu media tabel perkalian terhadap motivasi belajar matematika kelas II SD Negeri 1 Wates. Jenis penelitian ini adalah pre-experimental design dengan model One-Group Pretest-Posttest Design. Teknik pengumpulan data menggunakan angket, observasi, dokumentasi. Populasi penelitian adalah seluruh siswa kelas II SD Negeri 1 Wates. Berdasarkan olah data menggunakan uji t-test motivasi belajar siswa kelas II SD Negeri 1 Wates diperoleh $t_{\text {tabel }}=2,063$ dan $t_{\text {hitung }}=2,1919$ sehingga diperoleh 2,063 $<2,1919$ maka hipotesis ditolak, Dengan demikian dapat disimpulkan bahwa model Make A Match berbantu media tabel perkalian efektif terhadaap motivasi belajar matematika kelas II SD Negeri 01 Wates Kecamatan Kedungjati Kabupaten Grobogan.
\end{abstract}

Kata kunci: Model Make A Match, tabel Perkalian, Motivasi Belajar

\begin{abstract}
Motivation is something that encourages someone to learn or do an activity. Mc. Donald in Djamarah (2011: 148) says that motivation is a change of energy in someone's person that is characterized by the emergence of affective (feelings) and reactions to achieve goals. Low motivation to learn causes students to be less enthusiastic and not confident, so their desire or willingness to do something also decreases. By using the Make a Match learning model aided by multiplication table media is expected to be more effective against student motivation. This study aims to determine the effectiveness of the Make A Match model with the help of multiplication table media on the motivation to learn mathematics in grade II of SD Negeri 1 Wates. This type of research is a pre-experimental design with the One-Group Pretest-Posttest Design model. Data collected by questionnaires, observation, documentation. The study population was all second grade students of SD Negeri 1 Wates. Based on the data processing using the t-test of students' motivation in second grade students at SD Negeri 1 Wates obtained ttable $=2.063$ and tcount $=2.1919$ so obtained $2.063<2.1919$, the hypothesi rejected, thus it can be concluded that the Make A Match model assisted by media tables Effective multiplication of motivation to learn mathematics in class II of SD Negeri 01 Wates, Kedungjati District, Grobogan Regency.
\end{abstract}

Keywords: Make A Match model, media tables Effective multiplication, motivation 


\section{Pendahuluan}

Menurut Undang-Undang Sistem Pendidikan Nasional No.20 Tahun 2003 pasal 1 butir 1, pendidikan adalah: "usaha sadar dan terencana untuk mewujudkan suasana belajar dan proses pembelajaran agar peserta didik secara aktif mengembangkan potensi dirinya untuk memiliki kekuatan spiritual keagamaan, pengendalian diri, kepribadian, kecerdasaan, akhlak mulia, serta keterampilan yang diperlukan dirinya, masyarakat, bangsa dan Negara." Pendidikan nasional bertujuan: "untuk mengembangkan potensi peserta didik agar menjadi manusia yang beriman dan bertakwa kepada Tuhan Yang Maha Esa, berakhlak mulia, cakap, kreatif, mandiri, dan menjadi waarga Negara yang demokratis serta bertanggung jawab" (UU Sisdiknas No. 20 tahun 2003 pasal 3) (Ayu, 2017).

Pendidikan adalah hal terpenting bagi setiap negara untuk dapat berkembang pesat. Negara yang hebat akan menempatkan pendidikan sebagai prioritas pertamanya, karena dengan pendidikan, kemiskinan pada rakyat di negara tersebut akan dapat tergantikan menjadi kesejahteraan. Bagaimanapun, dalam perkembangannya, pendidikan di Indonesia senantiasa harus menghadapi beberapa masalah di setiap tahapnya. Masalahmasalah tersebut hanya dapat diselesaikan dengan partisipasi dari semua pihak yang terkait di dalam sistem pendidikan, seperti orangtua, guru-guru, kepala sekolah, masyarakat, dan juga peserta didik itu sendiri. Pada fase input, orangtua memiliki kontribusi besar dalam memperkenalkan nilai-nilai baik kepada anak-anak mereka. Orangtua bertanggung jawab penuh untuk mendidik anakanak mereka dengan nilai-nilai kepemimpinan, sehingga mereka mempunyai bekal yang cukup untuk menjadi cikal bakal pemimpin ketika mereka mulai memasuki institusi formal, seperti sekolah. Pada fase proses, orangtua bekerjasama dengan para guru dan kepala sekolah untuk memberikan penguatan kepada peserta didik dalam menerapkan nilai-nilai kepempinan yang baik melalui budaya organisasi di sekolah. Terakhir, pada tahap output, peserta didik harus menghadapi begitu banyak tantangan di dunia nyata, di luar sekolah. Peserta didik yang sudah melalui tahap-tahap sebelumnya di sekolah dengan budaya organisasi yang mengajarkan dan membiasakan nilai-nilai baik dalam hidupnya, maka akan tumbuh menjadi pemimpin yang hebat untuk negara ini (Megawanti, 2012).

Media POHICA (Papan Operasi Hitung Campuran) terhadap motivasi belajar matematika siswa kelas III SD Negeri Pandean Lamper 04 Semarang.

Berdasarkan latar belakang diatas, peneliti ingin mengujicobakan penelitian di SD Negeri 1 Wates Kabupaten Grobogan yang bertujuan untuk membuktikan penggunaan model pembelajaran Make A Match berbantu media tabel perkalian efektif terhadap motivasi belajar siswa. Selain itu, membuat siswa lebih aktif lagi dalam proses pembelajaran sehingga belajar akan efektif terhadap hasil belajar peserta didik lebih baik lagi. Berdasarkan Pendidikan Indonesia Nomor 20 tahun 2003 tentang Sistem Pendidikan Nasional pasal 1 ayat 1 mengemukakan bahwa "Pendidikan adalah usaha sadar dan terencana untuk mewujudkan suasana belajar dan proses pembelajaran agar peserta didik secara aktif mengembangkan potensi dirinya untuk memiliki kekuatan spiritual keagamaan, pengendalian diri, kepribadian, kecerdasan, akhlak mulia, serta keterampilan yang diperlukan dirinya, masyarakat, bangsa dan Negara".

Dalam hal untuk mewujudkan tercapainya tujuan pendidikan antara lain yaitu melalui kegiatan pembelajaran, pembelajaraan sendiri dapat dimaknai sebagai proses penambahan pengetahuan dan wawasan melalui rangkaian aktivitas yang dilakukan secara sadar oleh seseorang dan mengakibatkan perubahan dalam dirinya, sehingga terjadi perubahan yang sifatnya positif, dan pada tahap akhir akan didapat keterampilan, kecakapan dan pengetahuan baru (Saefuddin, 2016: 8). Sumber utama munculnya motif adalah dari rangsangan (stimulasi) perbedaan situasi sekarang dengan situasi yang diharapkan, sehingga tanda perubahan tersebut tampak pada adanya perbedaan afektif saat munculnya motif dan saat usaha pencapaian yang diharapkan. Motivasi dalam pengertian tersebut memiliki dua aspek, yaitu adanya dorongan dari dalam dan dari luar untuk mengadakan perubahan dari suatu keadaan pada keadaan yang diharapkan, dan usaha untuk mencapai tujuan (Uno, 2016: 9). 
Motivasi adalah sesuatu yang mendorong seseorang belajar atau melakukan suatu kegiatan. Mc. Donald dalam Djamarah (2011: 148) mengatakan bahwa motivasi adalah suatu perubahan energi di dalam pribadi seseorang yang ditandai dengan timbulnya afektif (perasaan) dan reaksi untuk mencapai tujuan. Dalam proses pembelajaran motivasi sangat diperlukan, sebab seseorang yang tidak mempuyai motivasi dalam belajar tidak akan mungkin melakukan aktivitas belajar. Karena motivasi belajar merupakan komponen pokok dalam pembelajaran, apabila dalam proses belajar tidak ada motivasi maka dalam pembelajaran kurang maksimal. Oleh karena itu motivasi belajar siswa penting dalam proses pembelajaran berlangsung dan perlu ditingkatkan.

Mengamati pentingnya motivasi belajar pada proses pembelajaran, dalam kenyataanya motivasi belajar siswa dalam proses pembelajaran cenderung rendah. Rendahnya motivasi belajar sehingga siswa kurang termotivasi untuk belajar dengan giat. Siswa cepat merasa bosan dalam mengikuti pembelajaran dikelas karena pembelajaran dikelas terasa monoton, sehingga siswa berbicara dengan teman ataupun asik sendiri dengan kegiatan yang dilakukan. Pada saat pembelajaran siswa pasif. Siswa masih belum percaya diri dengan kemampuan berhitung yang dimilikinya. Hal tersebut menyebabkan siswa kurang semangat dalam mengikuti pembelajaran dikelas. Kurangnya semangat belajar siswa dalam mengikuti pembelajaran, menyebabkan siswa belum sepenuhnya memahami materi yang telah disampaikan guru.

Berdasarkan temuan pengamatan yang dilakukan di SD Negeri 01 Wates ditemukan permasalahan bahwa motivasi belajar masih rendah. Hal ini dapat terlihat pada saat proses pembelajaran berlangsung, siswa kurang termotivasi untuk belajar dengan giat. Selain itu belum menggunakan model pembelajaran yang bervariasi serta belum sepenuhnya menggunakan media pembelajaran saat proses pembelajaran berlangsung. Pembelajaran yang dilakukan masih berpusat kepada guru. Pada saat proses pembelajaran berlangsung hanya menggunakan metode ceramah dan diskusi. Sehingga menyebabkan siswa kurang termotivasi untuk belajar serta menyebabkan siswa pasif saat mengikuti pembelajaran berlangsung. Adapun rendahnya motivasi menjadikan siswa kurang memahami materi yang disampaikan oleh guru maka proses pembelajaran dikelas menjadi kurang maksimal mengakibatkan siswa malas untuk mengikuti pembelajaran dikelas. Serta siswa juga kurang sepenuhnya mengembangkan kemampuan yang dimilikinya.

Rendahnya motivasi belajar mengakibatkan siswa kurang antusias dan tidak percaya diri maka keinginan atau kemauan untuk melakukan sesuatu juga menjadi berkurang. Proses pembelajaran belum bervariasi, sehingga menyebabkan siswa kurang antusias serta cenderung bosan dalam mengikuti pembelajaran berlangsung. Apabila siswa merasa bosan saat mengikuti pembelajaran akan timbul rasa malas untuk belajar yang mengakibatkan siswa belum sepenuhnya memahami serta menguasai materi yang disampaikan oleh guru. Menurut Uno (2011: 6) Motivasi terjadi apabila seseorang mempunyai keinginan dan kemauan untuk melakukan suatu kegiatan atau tindakan dalam rangka mencapai tujuan tertentu. Untuk itu, perlu adanya upaya untuk membantu meningkatkan motivasi belajar agar siswa lebih aktif pada saat pembelajaran berlangsung sehingga tujuan dari pembelajaran dapat tercapai. Maka guru dapat melakukan variasi pembelajaran misalnya menerapkan penggunaan model maupun media dalam pembelajaran.

Salah satu upaya yang diduga dapat mengatasi permasalahan diatas yaitu dengan mengujicobakan model pembelajaran Make $A$ Match, model ini memiliki karakterikstik yang berhubungan erat dengan karakter siswa yang gemar bermain. Pelaksanaan model Make $A$ Match didukung dengan keaktifan siswa untuk bergerak mencari pasangan kartu yang sesuai dengan jawaban atau pertanyaan dalam kartu tersebut. Siswa yang pembelajarannya dengan model Make $A$ Match aktif dalam mengikuti pembelajaraan sehingga dapat mempunyai pengalaman belajar yang bermakna (Shoimin, 2014: 98). Ciri utama model Make $A$ Match adalah siswa diminta mencari pasangan kartu yang merupakan jawaban atau keunggulan teknik ini adalah siswa mencari pasangan sambil belajar mengenai konsep atau topik dalam suasana yang menyenangkan (Shoimin, 2014: 98). Menurut Shoimin (2014: 99) Model Make $A$ Match ini mempunyai beberapa kelebihan, antara lain (a) Suasana kegembiraan akan tumbuh 
dalam proses pembelajaran, (b) Kerja sama antar-sesama terwujud dengan dinamis, (c) Munculnya dinamika gotong-royong yang realita diseluruh siswa. Penggunaan model pembelajaran ini, diharapkan dapat membantu guru dalam membangkitkan siswa dan mengaktifkan siswa agar lebih aktif dalam pembelajaran serta membuat siswa termotivasi dalam proses belajar mengajar. Tak hanya motivasi belajar siswa meningkat, dan juga siswa aktif pada saat proses pembelajaran berlangsung.

Berkaitan dengan model pembelajaran Make A Match berbantu dengan sebuah media, yaitu media tabel perkalian. Tebel perkalian merupakan sebuah alat yang digunakan untuk mencari informasi dalam bentuk tersusun, media ini mempermudah siswa dalam penguasaan perkalian. Tabel perkalian ini, cara pengajarannya yaitu berdasarkan jumlah digit bilangan yang terlibat, misalnya satuan, puluhan dan seterusnya.

Penggunaan model Make A Match terbukti berpengaruh terhadap motivasi pembelajaran matematika berdasarkan penelitian yang dilakukan oleh Hadiningsih (2018) terdapat pengaruh model Make A Match berbantu penjabaran permasalahan diatas, maka peneliti mengambil judul penelitian yaitu: "Keefektifan Model Make A Macth Berbantu Media Tabel Perkalian Terhadap Motivasi Belajar Matematika Kelas II SD Negeri 1 Wates".

Motivasi (motivation) adalah keseluruhan dorongan keinginan, kebutuhan, dan daya yang sejenis yang menggerakan perilaku seseorang (Wahab, 2015: 127).

Motivasi merupakan kekuatan (power motivation) daya dorong (diving force) atau alat pembangun kesediaan dan keinginan yang kuat dalam diri peserta didik untuk belajar secara aktif, kreatif, efektif, inovatif, dan menyenangkan dalam rangka perubahan perilaku baik dalam aspek kognitif, afektif, dan psikomotor (Suhana, 2014: 24)

Slameto (2010: 2) menyatakan bahwa belajar ialah suatu proses usaha yang dikaukan seseorang untuk memperoleh suatu perubahan tingkah laku yang baru secara keseluruhan, sebagai hasil pengalamannya sendiri dalam interaksi dengan lingkungannya.

Gange dalam Suparjiono (2015: 2) manyatakan bahwa belajar adalah berubahan disposisi atau kemampuan yang dicapai seseorang melalui aktivitas. Perubahan disposisi tersebut bukan diperoleh langsung dari diproses pertumbuhan seseorang secara alamiah.

Susanto (2013: 186-189) mengemukakan bahwa pembelajaran matematika adalah suatu proses belajar mengajar yang dibangun oleh guru untuk mengembangkan kreativitas berpikir siswa yang dapat meningkatkan kemampuan berpikir siswa, serta dapat meningkatkan kemampuan mengkonstruksi pengetahuan baru sebagai upaya meningkatkan penguasaan yang baik terhadap materi matematika.

Saifuddin (2016: 48) Menyatakan bahwa model pembelajaran adalah kerangka konseptual yang melukiskan prosedur sistematis dalam mengorganisasikan pengalaman belajar untuk mencapai tujuan belajar tertentu dan berfungsi sebagai pedoman bagi para perancang pembelajaran dan para pengajar dalam merencanakan dan melaksanakan aktivitas pembelajaran. Dalam hal demikian maka aktivitas pembelajaran benar-benar merupakan kegiatan pembelajaran yang benar-benar merupakan kegiatan yang bertujuan dan tertata secara sistematis.

Heinich dalam Arsyad (2016: 3-4) mengemukakan bahwa istilah medium sebagai perantara yang mengantar informasi antara sumber dan penerima. Jadi, televisi, film, foto, radio, rekaman, audio, gambar yang diproyeksikan, bahan-bahan cetakan, dam sejenisnya adalah media komunikasi. Apabila media itu membawa pesan-pesan atau informasi yang bertujuan intruksional atau mengundang maksud-maksud pengajaran maka media itu disebut media pembelajaran. Penelitian ini dilakukan untuk mencapai tujuan yaitu untuk mengidentifikasi keefektifan model Make $A$ Match berbantu media tabel perkalian terhadap motivasi belajar matematika kelas II SD Negeri 1 Wates Kabupaten Grobogan. 


\section{Metode}

Penelitian Dalam penelitian ini metode yang digunakan dalam penelitian ini adalah metode kuantitatif jenis metode eksperimen. Penelitian ini dilakukan dengan cara memberikan perlakuan kegiatan didalam belajar. Metode eksperimen digunakan untuk mencari pengaruh perlakuan model pembelajaran make a match berbantu media tabel perkalian terhadap motivasi belajar matematika. Mmetode penelitian yang menggunakan pendekatan kuantitatif, data penelitiannya berupa angka-angka yang selanjutnya dianalisis menggunakan statistik untuk menguji apakah hipotesis yang disimpulkan terbukti atau tidak (Sugiyono 2017: 14).

1. Desain Penelitian

Dalam kaitannya dengan pengunaan desain penelitian, peneliti dalam penelitian akan menggunakan sebuah metode yaitu metode Pre-Experimental Design, karena desain ini belum merupakan eksperimen sungguh-sungguh. Adapun karena masih terdapat variabel luar yang ikut berpengaruh terhadap terbentuknya variabel terikat dengan kata lain yaitu hasil ekseperimen yang merupakan variabel terikat itu bukan semata-mata dipengaruhi oleh variabel bebas (Sugiyono, $2018: 112$ ).

Ada rancangan metode Pre-Experimental Design dengan menggunakan bentuk desain penelitian yaitu One-Group Pretest-Posttest Design. Pada desain penelitian One-Group Pretest-Posttest Design maka pada desain ini terdapat pretest (angket), sebelum dan setelah diberikan perlakuan menggunakan model make a match berbantu tabel perkalian. Dengan demikian hasil perlakuan dapat diketahui lebih akurat, karena dapat membandingkan keadaan sebelum dan sesudah diberi perlakuan. Adapun desain ini dapat digambarkan seperti berikut:

(Sugiyono, 2018: 114-115)

\section{$\mathrm{O}_{1} \mathrm{X} \mathrm{O}_{2}$}

Keterangan :

$\mathrm{O}_{1}=$ Angket motivasi belajar sebelum diberikan perlakuan menggunakan model Make $A$ Match berbantu media tabel perkalian.

$\mathrm{O}_{2}=$ Angket motivasi belajar setelah diberikan perlakuan menggunakan model Make A Match berbantu media tabel perkalian.

$X=$ Pemberian perlakuan dengan menggunakan model Make $A$ Match berbantu media tabel perkalian.

Keefektifan model Make $A$ Match berbantu media tabel perkalian terhadap motivasi belajar matematika kelas II. = (O2 - O1) (Sugiyono, 2017: 75). Dengan prosedur rancangan sebagai berikut:

a. Lakukan pemberian angket awal (angket sebelum diberi perlakuan), untuk mengukur skor rata-rata sebelum subjek mendapat pelajaran menggunakan model Make $A$ Match berbantu media tabel perkalian .

b. Berikan perlakuan $\mathrm{X}$ yaitu Make $A$ Match berbantu media tabel perkalian.

c. Lakukan pemberian angket akhir (angket setelah diberi perlakuan), untuk mengukur skor rata-rata setelah subjek diberi perlakuan $\mathrm{X}$.

d. Membandingkan angket awal dan angket akhir, untuk mengukur ada atau tidak ada pengaruh sebagai akibat perlakuan $\mathrm{X}$, yaitu penggunaan model Make $A$ Match berbantu media tabel perkalian.

e. Perbedaan tersebut, bila ada diuji dengan teknik statistik yang sesuai untuk menentukan apakah perbedaan tersebut signifikan (berarti, bermakna).

f. Memberikan tafsiran/interpretasi atau member makna hasil pengujian statistik.

Maka untuk mengetahui hasil dari diberikannya perlakuan maka peneliti hanya membandingkan nilai skor angket motivasi belajar siswa sebelum dan sesudah dilakukannya pembelajaran. Nilai motivasi belajar (Pretest) diperoleh dari nilai pembelajaran tanpa menggunakan model Make A Match berbantu media tabel perkalian. Sedangkan nilai skor 
angket motivasi belajar (Posttest) di peroleh dari nilai pembelajaran dengan menggunakan model Make A Match berbantu media tabel perkalian.

Data merupakan sebagai sekumpulan informasi yang digunakan untuk menjawab permasalahan tersebut. Ada beberapa cara teknik pengumpulan data dalam penelitian ini.

1. Non tes

Instrumen non tes adalah instrumen selain prestasi belajar. Teori ini sesuai dengan (Sudaryono, 2012: 122). Alat penilaian yang digunakan antara lain adalah lembar angket. Dalam penelitian ini menggunakan teknik pengumpulan data non tes. Non tes digunakan untuk mengetahui motivasi belajar siswa kelas II SD Negeri 1 Wates Kecamatan Kedungjati Kapubaten Grobogan. Dalam melakukan penelitian ini, peneliti menggunakan beberapa cara teknik penggumpulan data untuk penelitian sebagai berikut:

\section{a. Observasi}

Observasi yang dilakukan peneliti dalam penelitian ini dengan cara pengamatan secara langsung ketika guru sedang melakukan pembelajaran dikelas, sembari mengamati guru dalam menyampaikan materi, mengamati model dan media yang digunakan guru pada saat pembelajaran berlangsung agar peneliti dapat menggunakan model pembelajaran dan media pemebelajaran yang cocok untuk siswa tersebut sesuai yang digunakan, serta respon dan perilaku siswa saat diberikan materi tersebut, serta mengamati bagaimana guru masalah siswa ketika siswa yang belum paham pada materi yang sedang diajarkan guru. Observasi ini dilakukan untuk memperoleh data motivasi siswa kelas II SD Negeri 1 Wates Kecamatan Kedungjati Kabupaten Grobogan.

\section{b. Dokumentasi}

Dalam penelitian ini, peneliti mengambil dokumentasi dilakukan oleh peneliti untuk memperoleh data berupa foto-foto dalam proses pembelajaran pada saat penelitian berlangung serta dokumentasi ketika siswa menggunakan tabel perkalian.

c. Kuesioner (Angket)

Pada penelitian ini, kuisioner atau angket digunakan untuk mengukur motivasi belajar siswa kelas II Negeri 1 Wates Kecamatan Kedungjati Kabupaten Grobogan. Bentuk angket yang digunakan ini yaitu bentuk angket tertutup. Dalam penelitian ini berupa pernyataanpernyataan yang berisi pernyataan negatif dan pernyataan positif. Siswa diminta untuk memberi tanda check $(\sqrt{ })$ pada butir-butir pernyataan yang sesuai dengan keadaan siswa. Skala motivasi yang di gunakan dengan menggunakan skala Likert. Skala Likert digunakan untuk mengukur sikap, pendapat dan presepai seseorang atau sekelompok orang tentang fenomena sosial. Hal ini sesuai dengan teori (Sugiyono 2015 : 93).

\section{Hasil Dan Pembahasan}

Penelitian ini berjudul "Keefektifan Model Make A Match Berbantu Media Tabel Perkalian Terhadap Motivasi Belajar Matematika Kelas II SD Negeri 01 Wates Kabupaten Grobogan". Penelitian ini dilakukan pada semester genap tahun pelajaran 2018/2019 dengan menggunakan satu kelas untuk penelitian. Dikarenakan hanya menggunakan satu kelompok saja maka hipotesis didasarkan perbedaan pada sebelum diberi perlakuan dan setelah diberi perlakuan dengan menggunakan model Make $A$ Match berbantu media tabel perkalian. Pemberian angket sebelum diberi perlakuan digunakan untuk memperoleh data awal, dan pemberian angket setelah diberi perlakuan digunakan untuk memperoleh data akhir. Setelah angket sebelum diberi perlakuan dan angket setelah diberi perlakuan dilakukan data yang diperoleh kemudian dianalisis untuk mengetahui pengaruh dari model Make $A$ Match berbantu media tabel perkalian melalui rerataan sebelum diberi perlakuan dan setelah diberi perlakuan. Alat pengumpulan data yang digunakan adalah angket yang berjumlah 30 butir pernyataan. Penelitian ini bertujuan untuk mengetahui efektif atau tidaknya model Make $A$ Match berbantu media tabel perkalian dalam meningkatkan motivasi belajar matematika Kelas II SD Negeri 01 Wates Kecamatan Kedungjati kabupaten Grobogan.

Sebelum melakukan penelitian, instrumen di uji validitas dengan salah validator atau ahli. Uji validitas intrumen angket di uji dengan salah satu ahli yaitu Ibu Eka Sari Setianingsih, S.Pd, 
M.Pd. Uji validitas instrumen dilakukan untuk mengetahui validitas angket yang akan digunakan dalam lembar angket sebelum dan sesudah diberi perlakuan. Lembar angket motivasi belajar terdapat 30 butir pernyataan dengan 14 butir pernyataan positif dan 16 pernyataan butir negatif. Adapun hasil dari validitas instrumen angket terdapat beberapa aspek yang divalidasi antara lain yaitu konsep, kontruksi, dan bahasa dengan dinyatakan setuju. Dengan kesimpulan dapat digunakan untuk penelitian dengan saran sebaiknya keterangan pilihan jawaban sangat sesuai, sesuai, dan cukup sesuai. Berdasarkan hasil uji validitas terdapat 30 butir pernyataan valid dan layak digunakan untuk penelitian, maka 30 pernyataan tersebut digunakan sebagai lembar angket sebelum diberi perlakuan dan angket setelah diberi perlakuan.

Dari hasil angket setelah diberi perlakuan, siswa sudah termotivasi dengan baik. Adapun skor yang didapatkan siswa pada hasil angket setelah diberi perlakuan motivasi belajar diperoleh skor rata-rata 98.17 dengan skor tertinggi 115 dengan skor nilai terendah 80 . Pada hasil angket diberi perlakuan terdapat 18 dari 24 siswa yang berada dalam katagori motivasi balajar tinggi dan enam siswa berada dalam katagori sedang.

Dari hasil angket sebelum diberi perlakuan dan setelah diberi perlakuan jika dibandingkan terdapat dalam beberapa kategori yaitu terdapat tujuh siswa yang mendapat peningkatan motivasi belajar dalam katagori sangat baik, 16 siswa mendapat peningkatan motivasi belajar dalam katagori baik, dan satu siswa mendapat peningkatan motivasi belajar dalam katagori cukup. Berdasarkan data tersebut dapat disimpulkan bahwa terjadi peningkatan motivasi belajar siswa setelah diberi perlakuan menggunakan model Make $A$ Match berbantu media tabel perkalian.

Berdasarkan perhitungan menggunakan uji t untuk mengetahui efektif tidaknya model Make A Match berbantu media tabel perkalian terhadap motivasi belajar matematika kelas II SD Negeri 01 Wates Kabupaten Grobogan. Kriteria pengujian hipotesis pada uji t yaitu jika $t_{\text {hitung }}$ $>t_{\text {tabel }}$ maka hipotesis ditolak dan jika $t_{\text {hitung }}<t_{\text {tabel }}$ maka hipotesis diterima. Jumlah $\mathrm{db}=24-1=23$ dan taraf signifikan $\alpha=5 \%$, maka diperoleh $t_{\text {tabel }}$ sebesar 2,063. Pada hasil perhitungan uji $t$ diperoleh $t_{\text {hitung }}$ sebesar 2,1919. Karena $t_{\text {hitung }}>t_{\text {tabel }}$ yaitu 2,1919 $>2,063$ maka hipotesis ditolak artinya model Make $A$ Match berbantu media tabel perkalian efektif terhadap motivasi belajar matematika kelas II SD Negeri 01 Wates Kabupaten Grobogan.

Analisis motivasi belajar siswa dilakukan untuk mengetahui peningkatan motivasi belajar siswa setelah diberi perlakuan dengan menggunakan model model Make $A$ Match berbantu media tabel perkalian. Hasil perhitungan analisis motivasi belajar diperoleh peningkatan motivasi belajar pada hasil angket sebelum diberi perlakuan dan angket setelah diberi perlakuan sebesar $11,7 \%$. Jika dikonsultasikan dengan kriteria peningkatan motivasi belajar termasuk dalam kategori baik. Dengan demikian dapat disimpulkan bahwa terjadi peningkatan motivasi belajar dengan menerapkan model model Make $A$ Match berbantu media tabel perkalian terhadap motivasi belajar matematika kelas II SD Negeri 01 Wates Kabupaten Grobogan.

Berdasarkan hal tersebut dapat disimpulkan bahwa model Make A Match Berbantu media tabel perkalian efektif terhadap motivasi belajar matematika kelas II SD Negeri 01 Wates Kabupaten Grobogan.

\section{Simpulan dan Saran}

Berdasarkan hasil penelitian yang telah dilakukan dapat disimpulkan bahwa model Make A Match berbantu media tabel perkalian terbukti efektif terhadap motivasi belajar matematika kelas II SD Negeri 01 Wates. Hal ini berdasarkan hasil penelitian menggunakan uji-t diperoleh $t_{\text {hitung }}>\mathrm{t}_{\text {tabel }}$ yaitu 2,1919 $>2,063$, maka $\mathrm{H}_{0}$ ditolak dan $\mathrm{H}_{\mathrm{a}}$ diterima artinya rata-rata skor angket motivasi belajar siswa sebelum diberi perlakuan lebih kecil dari rata-rata setelah diberi perlakuan. Dari data hasil penelitian terjadi peningkatan motivasi belajar sebesar $11,7 \%$ pada siswa kelas II SD Negeri 01 Wates Kecamatan Kedungjati Kabupaten Grobogan. Berdasarkan hal tersebut dapat disimpulkan bahwa model Make A Match berbantu media tabel perkalian 
efektif terhadap motivasi belajar matematika kelas II SD Negeri 01 Wates Kabupaten Grobogan.

Berdasarkan penelitian yang dilakukan di kelas II SD Negeri 01 Wates Kabupaten Grobogan, maka peneliti memberikan saran antara lain sebagai berikut.

1. Disarankan hendaknya model Make $A$ Match digunakan untuk pembelajaran selanjutnya atau mata pembelajaran yang lainnya sebagai alternatif pembelajaran dalam penggunaan model pembelajaran.

2. Model pembelajaran Make A Match berbantu media tabel perkalian jika digunakan dalam pembelajaran dikelas maka harus dikemas menjadi sebuah pembelajaran yang menarik dan menyenangkan sehingga peserta didik lebih aktif, pembelajaran lebih efektif dan efisien serta mampu meningkatkan motivasi belajar.

3. Pada saat proses pembelajaran berlangsung, harus memperhatikan sikap dan keaktifan siswa dalam kelas agar mampu meningkatkan motivasi belajar siswa.

4. Hendaknya model Make $A$ Match dapat dimanfaatkan dan digunakan oleh peneliti lain karena dapat meningkatkan motivasi belajar siswa.

\section{Daftar Rujukan}

Arikunto, Suharmini. 2010. Prosedur Penelitian Suatu Pendekatan Praktik. Jakarta: Rineka Cipta.

Arsyad, Azhar. 2016. Media Pembelajaran. Jakarta: Rajawali Press

Ayu, Nanda. 2017. Pendidikan Karakter Sebagai Pilar Pembentukan Karakter Bangsa . Fakultas IImu Sosial Universitas Negeri Medan Tahun 2017 Vol. 1 No. 1 2017, Hal. 348352

Djamarah, Syaiful Bahri, 2011. Psikologi Belajar. Jakarta. Rineka Cipta.

Hadiningsih, Azmi Indarti. 2018. Pengaruh Model Make A Match Berbantu Media POHICA Terhadap Motivasi Belajar Matematika Siswa Kelas III SDNegeri Pandean Lamper 04 Semarang. Skripsi Pendidikan Guru Sekolah Dasar. Fakultas IImu Pendidikan. Universitas PGRI Semarang.

Megawanti, Priarti. 2012. Meretas Permasalahan Pendidikan Di Indonesia . Jurnal Formatif 2(3): 227-234 ISSN: 2088-351X

Uno, Hamzah B. 2016. Teori Motivasi dan Pengukurannya. Jakarta: Bumi Aksara.

Saefuddin, H. Asis. 2016. Pembelajaran Efektif. Bandung: Remaja Rosdakarya.

Shoimin, Aris. 2014. 68 Model Pembelajaran Inovatif dalam kurikulum 2013. Yogyakarta: ArRuzz Media.

Slameto. 2010. Belajar dan Faktror-Faktor Yang Mempengaruhi. Jakarta: Rineka Cipta.

Sadirman. 2014. Interaksi dan Motivasi Belajar Mengajar. Jakarta: Rajawali PersS

Sudjana, Nana. 2005. Metoda Statistika. Bandung: Trasito.

Sugiyono. 2017. Metode Penelitian Kuantitatif, Kualitatif, dan R\&D. Bandung:

Alfabeta. 
Suhana, Cucu . 2014. Konsep Strategi Pembelajaran. Bandung: Refika Aditama.

Suparjono, Agus. 2016. Cooperative Learning Teori \& Aplikasi Paikem. Yogyakarta: Pustaka Belajar.

Susanto, Ahmad. 2013. Teori Belajar dan pembelajaran di Sekolah Dasar. Jakarta: Pernada Media Group.

Wahab, Rohmalina. 2015. Psikologi Belajar. Jakarta: Raja Grafindo Persada. 